\title{
COURT RECORDS: HISTORY IN THE MAKING, KNOWLEDGE FOR THE TAKING ${ }^{1}$
}

\section{BY THE HONORABLE LEONARD I. GARTH}

\author{
United States Circuit Judge \\ U.S. Court of Appeals for the Third Circuit
}

I T HAS only been of recent date that organizations such as the Historical Society of the United States District Court for the District of New Jersey and the Historical Society of the Third Circuit have come into being, in order to fill a void in sore need of being filled. This void may have occurred because, for reasons still unfathomed, historians by and large have traditionally ignored court records as a source of historical research. It may be that they have done so because, not having been trained primarily in the law, historians have not been attracted to, or may be unaware of, the rich historical lore that is buried in judicial records. Or, it may be because a basic lack of familiarity with the legal discipline has led historians to discount the historical value of materials found in these records. By doing so, they may very well have forfeited an understanding of those events which preceded, and then succeeded, a particular case decision - events that may have had an influence on the future directions that our society has taken. More likely, in my judgment, the failure to study and analyze court records from an historical perspective, stems from a combination of these factors, as well as others, to which I have not adverted.

Whatever the reason, however, even a hurried and abbreviated journey through early court dockets reveals to us now that the problems facing us today have had in many instances their genesis in years past, and that the events giving rise to those problems may, when examined and understood, possibly provide assistance in solving the 2oth Century concerns presently confronting us. Indeed, it should come as no surprise to us that

Judge Garth presented this paper at the opening of the Exhibit "Thirty Stripes, One Hundred Dollars or Six Months Imprisonment: Federal Courts in New Jersey, 1789-1989" at Alexander Library, Rutgers University, on 18 September I 989. The exhibit was sponsored by the U.S. National Archives-Northeast Region, The Historical Society of the United States District Court for the District of New Jersey, and Rutgers University's Department of Special Collections and Archives. 
issues which are now front-page topics, such as the devastation caused by, and the disposition of, toxic wastes; the ever-present fight against use and distribution of illegal substances; and the impact of crime on our citizens and communities are but a few of the problems encountered today-problems that have been encountered, albeit in different forms and at different times, during the 200 years that the federal courts have existed in New Jersey and throughout our nation.

Because I have not devoted myself to historical research in these fields, my mission in this paper is limited to stimulating the interest of those who have not as yet appreciated the richness of the resources available in court records, and to commenting briefly on some of the contributions made through the years by our federal courts as they relate to the District of New Jersey. In addition, I will draw parallels between today and yesteryear's historical events of significance, and examine the additional difficulties facing the New Jersey federal judiciary in its efforts to cope with these vital concerns while still maintaining the high judicial standards set by its predecessors.

\section{I.}

The most obvious starting point, of course, is the beginning. No recitation in the areas on which I am about to discuss would be complete without a prologue as to how, when and why the federal district court and its reviewing tribunal, the Court of Appeals, came into existence. When adopted, the Constitution of the United States provided for a Supreme Court and such inferior courts as the Congress should establish. The Constitutional Convention in 1787 had resolved the judiciary issue by providing that Federal Courts, separate from existing state courts, should be established. Indeed, the First Congress had a unique opportunity. The Congress could now establish a judicial system for a brand-new nation without having the form of the judicial structure dictated by traditions or old-world considerations. Erwin C. Surrency, in his "History of the Federal Courts," writes that

The authors of the first Judiciary Act came from states with an established judicial system that had, in many cases, been functioning for over a century. Several of these individuals had been involved in restructuring the judicial system in their own states, making changes in jurisdiction and powers of the colonial courts. One concern was the need to separate the judicial functions from the executive, for in the Royal Colonies, the governor was the chan- 
cellor, probate judge, and chief judge in the Courts of Appeals. When the members of the Congressional Committee drafted the first Judiciary Act, this experience of establishing the judicial systems in the states provided some guidance in establishing the Federal Courts.

Of course, the experience of the State Courts was not the only experience to which the First Congress looked. They also looked to the English Courts and built into this new judicial system a number of features derived from the English practice.

The Judiciary Act of I 789 provided for three Circuits - the Southern, Middle, and Eastern. The Middle Circuit, which is of most interest to us because it was the Third Circuit's predecessor, included the states of Pennsylvania, New Jersey, Delaware, Maryland, and Virginia. Under the Judiciary Act of $180 \mathrm{I}$, the "Third Circuit," consisting of Pennsylvania, New Jersey, and Delaware, made its first appearance in the Federal judiciary. That Act divided Pennsylvania and New Jersey into Eastern and Western Districts, but did not create new judicial positions for those districts. Rather, the District Judges for Pennsylvania and New Jersey were to hold Court in both Eastern and Western Districts. I mention this feature in particular because in reviewing the very early Federal cases, little distinction was made between the cases arising from and decided by New Jersey and Pennsylvania judges.

In 1802 , in a Second Judiciary Act, the size of the three original circuits was reduced and three more were added. The new Third Circuit was somewhat different from the Third Circuit created under the I80 I Act because it included only Pennsylvania and New Jersey. In I 866, Congress transferred the District of Delaware from the Fourth to the Third Circuit as part of a general plan to redistribute the states among the Circuits. Since that time, the states constituting the Third Circuit have remained the same, except for the addition of the Territory of the Virgin Islands which took place in 1948 .

In I 89I, the Circuit Court of Appeals Act was promulgated. This Act created an intermediate Appellate Court for the Federal Judiciary. Professor Presser, in his study of the United States Courts of the Third Circuit, notes that social and economic changes were particularly pronounced in the states of the Third Circuit during this period of time. Anthracite mining in Eastern Pennsylvania, oil drilling in Western Pennsylvania, and steel production in Pittsburgh, had catalyzed economic development and increased the population growth and urbanization of those areas. At the same time, he notes that Northern New Jersey had become a major 
industrial center, and both New Jersey and Delaware, with their liberal incorporation statutes, had become havens for corporations.

Thus it was that in I90 I Congress, responding to the Third Circuit's increased load as it did in other judicial circuits, by increasing judicial personnel and dividing the circuits into districts, carved out the Middle District of Pennsylvania from portions of the Eastern and Western Districts. New Jersey remained one district throughout this period of growth, although from time to time since then, consideration has been given to dividing New Jersey into two and sometimes even three districts which would resemble in some aspects, the three vicinages of the New Jersey District itself, that is the northern (Newark) vicinage, the middle (Trenton) vicinage, and the southern (Camden) vicinage.

It was through these legislative efforts that the present form and structure of the federal judiciary took shape. It does not take much imagination to envisage the strains and stresses experienced by the Congress that resulted in each of the Judiciary Acts which the legislature enacted. That struggle, of course, still goes on, and the present day participants in similar ventures such as Congress' newly constituted Federal Courts Study Committee may well harken back to the earlier experiences of Congress in the creation of the circuits and districts to guide their hands.

It was not long ago that the Fifth Circuit was divided into the Fifth and Eleventh Circuits in order to provide for increased judicial efficiency. Even today, in an effort to improve our federal courts, the structure of the entire court system is again undergoing examination, particularly in light of the overwhelming case loads that the Federal Courts have been experiencing. Last year, Congress established the Federal Courts Study Committee, which has as one of its mandates the study of the federal court structure, and one of the innovative suggestions under consideration by that Committee is the abolition of all Courts of Appeals by circuit designation and its replacement by one national court of appeals with a multitude of divisions, thereby permitting judges to be moved freely from one area of the country to another to respond to judicial needs.

The problem of court structure, however, has not been the only judicial problem that has engaged the Congress. Selection of personnel to staff the courts has been equally vexing, both in terms of the numbers of judges and the identity of them. I need only point to the Senate hearings of recent date at which Judge Bork's nomination to the Supreme Court was rejected and Chief Justice Rehnquist's nomination as Chief Justice was confirmed. Those hearings brought before the public once again the very issues of accountability and responsibility that were debated so vigorously at the 
original Federal Convention some 200 years ago. Indeed, it was at that convention that Max Farrand reported Benjamin Franklin's observations in his "Records of the Federal Convention of I 787." Benjamin Franklin observed that two modes of choosing judges had been under discussion, that is, the choice by the Legislature or by the Executive. In discussing other modes, he mentioned one mode which he understood was practiced in Scotland. He related that the Scottish mode entertained the judge's nomination by his fellow lawyers, who always selected the ablest of their profession in order to get rid of him and to share his practice among themselves. We know today, of course, that federal judges are nominated by the President and confirmed by the Senate, a result possibly of Dr. Franklin's observation.

Let me digress for a moment to comment briefly on the present state of our federal judiciary as contrasted with the courts not as they existed 200 years ago, but rather as they discharged their functions as recently as in the years I 945, I950, and I 960. I have mentioned earlier that the Federal District Court of New Jersey and the Court of Appeals of the Third Circuit, which reviews the judgments of the Federal District Courts of the District of New Jersey, as well as the judgments of the District Courts of Pennsylvania, Delaware and the Virgin Islands, have been faced not only with substantive problems that may have occurred in one guise or another in the past, but each court has also been compelled to meet the ever-increasing volume of cases that have flooded its dockets. I think it is pertinent to describe the situation our courts are currently facing, and why it is so imperative that we utilize every resource in order to maintain the viability of an effective judiciary. Let me cite just a few statistical examples to indicate the enormity of this situation.

In I 945 , the district courts - and I speak now of the district courts nationally-had I00,000 filings. In I 988 , this number had increased to 285,000 , or an increase of I 83 percent. During the same period, however, the filings in the courts of appeals increased from 2700 in 1945 to 37,500 in I 988 - an increase of I, 275 percent. In I 945 , one appeal was filed for every 42 district court terminations. In I 988 , one appeal was filed for every eight district court terminations. On a personal note, let me just say that when I joined the Court of Appeals in the early I 970's, we sat six times a year with I 6 cases per sitting, or a total of 96 cases, each of which was orally argued and each of which resulted in a written opinion. In 1988 , the number of merits-based terminations for the average court of appeals judge had risen to 369 and this, of course, does not take into account the motions, en banc hearings, or other administrative obli- 
gations which fall to each member of the court. Perhaps the greatest growth is found in prisoner petitions. In 1960, I I I prisoner petitions were filed. In 1988, 7,294 were filed, an increase of 6,47 1\%. Again-in 1950, only one out of every I 2 I district court criminal case terminations resulted in appeal. The figure for 1988 is I out of every 7. Parenthetically, one might wonder why it is not I out of I, particularly since appeals by indigent defendants are financed by the government. I suspect that the answer - although I have no empirical evidence to substantiate it - is that some of those 7 terminations were guilty pleas and others were convictions which resulted in probationary and not jail sentences.

Without belaboring the point that the courts have experienced a growth in caseload which is unprecedented, it should be noted that without various procedural innovations and adaptations such as elimination of oral argument, development of screening procedures, disposing of cases without published decisions, and the like, the Court of Appeals would have been unable to manage its workloads. It is evident, however, that these case management innovations alone will not enable the courts to deal with their growing caseloads. Major structural changes comparable to those enacted by the Congress in our very early years will be necessary if the Federal Judiciary is to meet the ever-changing judicial needs of this nation. But let me return to the earlier question that I posed for answer: will a more complete understanding of past events giving rise to court adjudications assist us in coping with both structural and substantive programs in the future?

II.

With this very brief and superficial historical recitation as background, and bypassing the problems of our current courts to which I have just adverted, let me touch on some court decisions-some significant and some not quite so important-which arose in New Jersey or were decided by the federal courts of this district. Whether a high profile case or not, each contributed in some measure to the later development, not only of our jurisprudence, but of the manner in which our society thereafter dealt with the issues presented.

One such firm image we have today is of the impartial jury. As a matter of interest, you undoubtedly know that our present jury procedures require the complete insulation and isolation of jurors. This requirement had its origin many years ago. As early as I 820, Justice Washington, in the District of New Jersey, discussed at great length the furnishing to 
jurors of food and drink which were ordered for them by the plaintiff in the case.

Another firm image held today is the reaction of the judiciary to slavery. Thus, three years later, in 1823 , the same Justice refused to return a slave to South Carolina, holding that the particular fugitive statute under which the slave's return was sought, and which proscribed escape by fugitives from one state to another, did not apply when, as was the situation in the case before him, the slave was voluntarily brought by his master to our state.

For reasons which are not pertinent here, the New Jersey federal reports contain very little in the way of criminal cases, and as I earlier noted, it was during this early period that Pennsylvania and New Jersey judges sat on cases from either jurisdiction. In this connection I refer again to Justice Washington, who discussed the competency of a witness to testify where the witness appeared in a criminal case testifying for the prosecution. The objection had been made that, because the witness had been previously convicted of an assault and battery with an intent to murder and had been sentenced to pay a fine and serve two periods of six months imprisonment, he was incompetent to testify at the criminal trial of another. The opinion of Washington in this case is of interest, particularly in light of the title of the current exhibition "30 Stripes, I Oo Dollars or 6 Months Imprisonment." The opinion reads as follows:

The punishment of this offence at common law, is fine and imprisonment, and frequently the pillory is added; but it seems to be in the discretion of the court. In lieu of the common law punishment of branding, whipping, and pillory, the Penal Code of this state, has substituted confinement and hard labour. Now, even if the incompetency produced by conviction, depended on the punishment, instead of the nature of the offence; where the infamous punishment forms no part of the sentence, there would be no disqualification, because it might have been inflicted. In this case, the punishment by fine and imprisonment, is not to be considered as an infamous punishment, so as to render the witness incompetent.

Today, of course, in an effort to eliminate disparate sentences for the same crime, our federal courts, obeying the Congressional mandate, now impose sentences prescribed by the Sentencing Guidelines.

While this smattering of cases does no more than impart a flavor and perhaps some insight as to the subjects dealt with by earlier courts. I am sure, in light of current jurisprudence-and I refer specifically to the recent furor occasioned by the Supreme Court's "Flag Burning" case- 
you will be interested to know that one of the very early First Amendment cases was heard in the Third Circuit and involved the expulsion from public school of two students who had refused to salute the flag as part of the school exercise.

The students Lillian and William Gobitis were members of "Jehovah's Witnesses." Because their religious beliefs proscribed the recitation of a pledge of allegiance to a flag as a form of idolatry, they were obliged to leave school. The District Court enjoined the school from requiring the minor plaintiffs to salute the flag as a condition of their right to schooling and that decision was affirmed by the Third Circuit-a court in which I am proud to claim membership. The Supreme Court, however, took a contrary view, but that view did not persist. Two years after the Supreme Court's reversal of the Third Circuit, the Supreme Court in Barnett v. West Virginia rethought its position and upheld the principle that a compulsory pledge of allegiance for children in the public schools violates the First and Fourteenth Amendments. Thus, it overruled its prior decision in the Gobitis case and enjoined the West Virginia legislation which required mandatory participation by students in the flag salute. In rejecting the doctrine espoused in its Gobitis opinion that "national unity is the basis of national security," and that accordingly, compulsory measures leading toward "national unity" [i.e. compulsory pledges of allegiance] are constitutional. The Supreme Court in Barnett, speaking through Mr. Justice Jackson said:

National unity as an end which officials may foster by persuasion and example is not in question. The problem is whether under our Constitution, compulsion as here employed, is a permissible means for its achievement. Struggles to coerce uniformity of sentiment in support of some end thought essential to their time and country, have been waged by many good as well as by evil men. Nationalism is a relatively recent phenomenon but at other times and places, the ends have been racial or territorial security, support of a dynasty or regime, and particular plans for saving souls. As first and moderate methods to attain unity have failed, those bent on its accomplishment must resort to an ever-increasing severity. As governmental pressure toward unity becomes greater, so strife becomes more bitter as to whose unity it shall be. Probably no deeper division of our people could proceed from any provocation, than from finding it necessary to choose what doctrine and whose program public educational officials shall compel youth to unite in embracing. Ultimate futility of such attempts to compel coherence, is the lesson of every such effort from the Roman drive to stamp out Chris- 
tianity as a disturber of its pagan unity, the Inquisition, as a means to religious and dynastic unity, the Siberian exiles as a means to Russian unity, down to the fast failing efforts of our present totalitarian enemies. Those who begin coercive elimination of dissent, soon find themselves exterminating dissenters. Compulsory unification of opinion achieves only the unanimity of the graveyard.

A similar appreciation of the toleration of diverse thought in a democratic society was evinced in another, perhaps less well-known New Jersey District Court case-U.S. v. Hautau, which was decided in 1942 , the opinion being rendered by District Judge Fake. That opinion rejected a requirement that employees of the Works Progress Administration file an affidavit that they were not Communists. The WPA is best known to us for the artwork which adorns many of the post offices and courthouses of our land. I might note parenthetically, that this is another instance in which history has repeated itself. If I may detour a bit-although we had the WPA in pre-World War II years, today we have a "Living Buildings" program which encourages art exhibits in our federal buildings. It was not long ago that a furor erupted in the Federal Courthouse in Philadelphia, where the Court of Appeals sits and where the Eastern District of Pennsylvania District Court judges hold court. One of the paintings that graced the courthouse walls depicted a nude woman with her breasts exposed. The Chief Judge of the Eastern District of Pennsylvania felt that such an exhibit was inappropriate and ordered the painting removed. This in turn led to a lawsuit which was ultimately settled by agreement among all parties - the landlord Government Services Administration, the tenants, i.e., the court, and the judges-that future exhibits would be carefully monitored. I note also that, in much the same context, Senator Jesse Helms recently advocated a Bill which would delete federal appropriations for "offensive" artwork.

Returning to our discussion of the Hautau case:

Judge Fake in that case refused to enforce the sanctions of the legislation because he found the statute requiring the Communist affidavit to be "so vague as to require the quashing of the indictment." In doing so, he referred to a Supreme Court case (Lanzetta v. New Jersey, 306 U.S. 45 I [1939]) which had its origins in New Jersey, although not from the New Jersey District Court, but rather, from the New Jersey Supreme Court.

A New Jersey Statute sought to proscribe gangsterism-a gangster being defined as "one not engaged in any lawful occupation, known to be a member of any gang consisting of two or more persons, and who had 
been convicted of being a disorderly person or convicted of any crime in any state." If some of you are under the impression that the RICO legislation-that is the Racketeer Influenced and Corrupt Organizations Act - is new to the criminal enforcement field, let me point out that this type of legislation was presaged by the New Jersey act some fifty years ago. In Lanzetta, of course, the Supreme Court condemned as "repugnant to the due process clause of the Fourteenth Amendment" the New Jersey statute, holding that it was virtually incapable of definition. As Justice Butler wrote, "The Statute fails to indicate what constitutes membership or how you can join a gang."

The case of New Jersey v. New York City, 283 U.S. 473 ( I 93 I), provides still another excellent example of a past but recurrent problem which continues to plague our communities. The City of New York had for a number of years been disposing of garbage in the Atlantic Ocean, which washed ashore, despoiling our beautiful New Jersey coastline. New Jersey brought suit, although not in the District Court of New Jersey, but in the United States Supreme Court in accordance with its original jurisdiction over disputes between states. New York's argument was that it had lawful permits, that it was supervising the dumping, and that anyway "garbage was garbage" and the ocean belonged to everyone.

The United States Supreme Court upheld the issuance of an injunction against the State and City of New York, and ordered that sea dumping not be allowed to proceed absent greater regulation. This case and its progeny have led to a number of compromises between New York and New Jersey, and repeated congressional intervention. Most recently in the case of Philadelphia v. New Jersey, 437 U.S. 617 (1978), the State of New Jersey once again sought to keep out-of-state garbage out of the state. New Jersey tried to get around the obvious freedom of interstate commerce argument by claiming that useless, toxic, and noxious waste was of no value and, therefore, not to be protected by interstate commerce principles. New Jersey lost this time . . garbage may be transported freely interstate. This controversy, of course, is a continuing one-and we have not seen the last of this type of dispute.

Of course, even before the states could sue each other over dumping garbage, it was necessary to determine where exactly the states began and ended. In the case of New Jersey, this was not self-evident. In fact, among the oldest of the cases decided by the United States Court of Appeals for the Third Circuit is the case of Corfield $v$. Coryell, decided in I 823 (4 Washington Circuit Court Reports, 37 I) which helped to establish New Jersey's southern, western, northern, and eastern borders. This case in- 
volved a challenge to the laws of the State of New Jersey as they applied to the Delaware Bay and the Delaware River. The Court, Supreme Court Justice, Bushrod Washington and Honorable Richard Peters, sitting, were confronted with the issue of the boundaries of the states of Delaware, Pennsylvania, and New Jersey. More specifically, they were confronted with interpreting the Charter of King Charles II to his brother, the Duke of York, in I663, and the Charter to William Penn in $\mathrm{I} 682$.

The Court addressed the subject of conflicting grants of land from the Duke of York to William Penn and other grants to other colonies at other times. The Court, after investigating the historical material relevant to this case, established the precise boundaries of these three states while it also established New Jersey's boundary with the State of New York. These are the boundaries governing to this very day. All of this was, by the way, done incidentally, in the course of establishing the validity of a law in the State of New Jersey regulating fishing for oysters.

The few cases that I have discussed are just a sampling of the matters with which our courts have dealt. I have not attempted by any means to be exhaustive in this respect. I have only endeavored to point out that some of the problems that we recognize today and which we believe are new and unique to our generation have been explored, if not in the same dimension, at least in a similar context, in prior generations. It may be that the experiences of our forefathers might well guide our hands in dealing with similar problems today.

I note, for instance, that Chief Judge Gibbons of the Court of Appeals for the Third Circuit, when he spoke before the Historical Society of the District Court of New Jersey some few years back, referred to the Volsted Act, which forbade the sale or use of liquor. He spoke to the problems encountered with Volsted Act enforcement in this state. He suggested that one could equate the actions taken in Volsted Act cases with the actions being taken today in substance abuse cases, and he asked questions such as:

What was the record of prosecutions?

How did prosecutions fare in those cases which went to trial?

What kind of sentences were imposed?

Did the Executive Branch mount a serious enforcement issue?

Did the Judiciary assist or frustrate that effort?

Do those questions which Judge Gibbons asked, and which I have now repeated, raise similar questions in your mind with respect to the drug malady which afflicts this nation and, of course, this state? Is it possible 
that the historical patterns that evolved from the enforcement of acts such as the Volsted Act could assist us in dealing with our present day acute drug problems? If so, shouldn't the records of those cases be studied in the hopes, and to the extent, that they may bear upon solutions to the problems with which we are concerned today?

In this connection, can we learn as well from the other criminal cases tried in this district how to avoid or remedy the excesses which gave rise to those prosecutions? I am sure that all of us here remember, or are familiar with, the municipal corruption prosecutions which took place in New Jersey in the early I970's and which led to prosecutions in other jurisdictions along similar lines. Would a study of the cause and consequences of such actions as reflected in court records provide material from which society can learn how to better its present day institutions and their operations?

As you can tell, I believe that such an examination and research can be invaluable. I know that my colleagues share the same views, otherwise, we would not have historical societies such as the District of New Jersey has formed and the Third Circuit has chartered. Thus, it is that I find F.A. Hayek's statement in Capitalism and the Historians to be apt:

While the events of the past are the course of the experience of the human race, their opinions are determined not by the objective facts but by the records and interpretations to which they have access. Few men will deny that our views about the goodness or badness of different institutions are largely determined by what we believe to have been their effects in the past.

The Federal Courts in New Jersey, now approaching their 2ooth anniversary, have-like the State Courts of New Jersey - enjoyed an illustrious history. They have contributed notably to the growth of liberty in our land. They have helped expand the frontiers of social policy, while also balancing the right of an individual initiative. They have restrained the powers of government, while also, where necessary, backing them up. In all modesty, we have done our share and done it well. We can only aspire to being as successful over the next 200 years as our colleagues have been over the past 200! But we should learn and profit from them-from their successes and failures - and we can only accomplish that task by studying, inquiring and analyzing their experiences. 